\title{
SIFAT POLIMER DAN KEMAMPUAN TERBIODEGRADASI BLEND BIODEGRADABLE POLYMER POLI (L-ASAM LAKTAT) (PLLA)
}

\author{
Johnner Sitompul ${ }^{*}$, Rizki Insyani, Daniel Prasetyo, Hermawan Prajitno, dan \\ Hyung Woo Lee ${ }^{*)}$
}

\author{
Program Studi Teknik Kimia, Fakultas Teknologi Industri, Institut Teknologi Bandung \\ Jl. Ganesha 10, Bandung, 40132 \\ Telp: (022) 2500989, Fax: (022) 2501438 \\ ${ }^{*}$ Penulis korespondensi: sitompul@che.itb.ac.id dan leehw@che.itb.ac.id
}

\begin{abstract}
POLYMER PROPERTIES AND BIODEGRADIBILITY OF BLEND BIODEGRADABLE POLYMER POLY (L-ASAM LAKTAT) (PLLA). This paper concerns on blending method of Poly(D,L-lactic acid) (PDLLA) and poly(ethylene glycol) (PEG) to modify mechanical and biodegradability properties of poly(L-lactic acid) (PLLA) through solution blending method using solvent mixture of dichloromethane-ethanol. Polymer samples were then characterized using FTIR, DSC, UTM, and enzymatic degradation test. FTIR spectrum of pure PLLA showed specific IR absorption peaks at respective wave number. Further, polymer blend samples showed absorption peak shifts at $1755 \mathrm{~cm}^{-1}$ and $1382 \mathrm{~cm}^{-1}$ for PLLA/PDLLA due to stereocomplex interaction and at $3429 \mathrm{~cm}^{-1}$ due to hydrogen bond interaction. DSC results showed that there was melting temperature depression for all polymer blend samples compared to pure PLLA with increasing of either PDLLA or PEG composition. In PLLA/PDLLA, two melting points were found because of homocrystallite and stereocomplex phase formation. While PLLA/PEG samples showed increasing crystallinity to $69 \%$ at 20\%-wt PEG composition. Mechanical analysis showed that 10\%-wt of PDLLA addition in PLLA produced better mechanical performance than pure PLLA while 20\%-wt of PEG addition showed highest elongation at break with the value of $89 \%$. Polymer blend samples were degradable during enzymatic degradation test represented by percent weight loss with maximum value of $21 \%$ for PLLA/PEG sample.
\end{abstract}

Keywords : enzymatic degradation; Poly(lactic acid); polymer blend; polymer properties; solutionblending

\begin{abstract}
Abstrak
Makalah ini membahas metoda blending Poli(D,L-asam laktat) (PDLLA) and poli(etilen glikol) (PEG) dalam upaya modifikasi sifat mekanik, sifat termal dan sifat terbiodegradasi dari poli(L-asam laktat) (PLLA) melalui suatu metoda solution blending dengan solven berupa campuran dichlorometan-etanol. Sampel-sampel dari polimer dikarakterisasi menggunakan FTIR, DSC, UTM dan uji degradasi enzimatik. Spektrum FTIR dari PLLA murni menghasilkan puncak absorpsi spesifik IR pada panjang gelombang tertentu. Lebih jauh, sampel dari polymer blend PLLA/PDLLA menghasilkan pergeseran puncak absorpsi pada panjang gelombang $1755 \mathrm{~cm}^{-1}$ dan $1382 \mathrm{~cm}^{-1}$ karena terbentuknya interaksi stereocomplex dan pada $3429 \mathrm{~cm}^{-1}$ karena interaksi melalui ikatan hidrogen. Hasil analisa DSC menunjukkan terjadinya perubahan temperatur leleh untuk seluruh sampel-sampel polymer blend dibandingkan PLLA murni, khususnya dengan meningkatnya komposisi PDLLA atau PEG dalam polymer blend. Untuk blend PLLA/PDLLA, terbentuk dua temperatur leleh dikarenakan pembentukan fasa homocrystallite dan stereocomplex. Sementara itu, sampel-sampel PLLA/PEG menghasilkan peningkatan konsentrasi kristalinitas menjadi 69\% pada komposisi 20\%-b PEG. Hasil analisa pengukuran sifat mekanik menunjukkan bahwa penambahan sebesar 10\%-b PDLLA ke PLLA murni akan memberikan sifat mekanik yang lebih baik dari PLLA murni, sedangkan penambahan 20\%-b PEG menghasilkan sifat elongation at break tertinggi sampai peningkatan nilainya sebesar 89\%. Untuk sifat terbiodegradasi, sampel-sampel polymer blend terbiodegradasi secara enzimatik dengan prosentase kehilangan maximum sampai sebesar $21 \%$ untuk blend sampel PLLA/PEG.
\end{abstract}

Kata kunci : degradasi enzimatik; Poli(asam laktat); polymer blend; sifat-sifat polimer; solutionblending 
How to Cite This Article: Sitompul, J., Insyani, R., Prasetyo, D., Prajitno, H., dan Lee, H.W., (2014), Sifat Polimer dan Kemampuan Terbiodegradasi Blend Biodegradable Polymer Poli(L-Asam Laktat) (PLLA), Reaktor, 15(2), 7986, http://dx.doi.org/ 10.14710/reaktor.15.2.79-86

\section{PENDAHULUAN}

Konsumsi plastik berbasis petro-based polymer sebagai bahan baku produk komersial akan semakin meningkat dari tahun ke tahun seiring dengan meningkatnya populasi dan kebutuhan manusia serta perkembangan teknologi. Produksi plastik konvensional berkontribusi pada dampak lingkungan yaitu penggunaan minyak bumi, emisi gas $\mathrm{CO}_{2}$, dan limbah plastik yang tidak terdegradasi. Untuk mengurangi resiko kerusakan lingkungan yang diakibatkan oleh hal tersebut, kini telah banyak diproduksi material ramah lingkungan berbahan baku plastik yang berasal dari biomassa dan memiliki kemampuan terdegradasi secara alamiah. Upaya untuk produski asam laktat sebagai platform chemical (kimia dasar) dari biomassa (sangat gencar dilakukan karena Poli(asam laktat) (PLA) dari LA terbarukan akan membuat PLA akan realtif mudah sekali terbiodegradasi sebagai suatu life cycle yang hampir sempurna (Sitompul dkk., 2014). PLA merupakan poliester termoplastik yang memiliki atom $\mathrm{C}$ asimetrik atau kiral sehingga memiliki tiga jenis struktur polimer yang berbeda yaitu poli(L-asam laktat) (PLLA), poli(D-asam laktat) (PDLA), dan poli(D,Lasam laktat) (PDLLA) (Auras dkk., 2010; Rein, 2010). Poli(L-asam laktat) (PLLA) telah diketahui sebagai biodegradble polymer sejak tahun 1960 (Park dkk., 1999) dan telah banyak digunakan sebagai biomaterial dalam aplikasi biomedis seperti material implant, jahitan operasi, dan sistem penghantar obat terkontrol karena memiliki sifat biokompatibilitas dan biodegradabilitas yang baik (Tsuji, 2005; Pan dkk., 2009; Park dkk., 1999)

Poli (L-asam laktat) (PLLA) merupakan bioplastik yang memiliki potensi sebagai alternatif substitusi polimer berbasis minyak bumi karena PLLA memiliki sifat fisik polimer termoplastik, modulus elastisitas yang tinggi serta dapat diproses (Pan dkk., 2009; Hirata dan Kimura, 2010). Penggunaan PLLA sebagai bahan mentah dalam industri polimer juga menjadi solusi untuk mengatasi beberapa masalah lingkungan terutama dalam hal limbah plastik yang tidak dapat terdegradasi di alam dengan mudah. Bagaimanapun juga, PLLA memiliki kekurangan yang membatasi penggunaannya dalam beberapa aplikasi tertentu. Pada aplikasi komersial, dalam proses produksi material pembungkus skala besar (film and sheet casting, stretch blow molding dan injection molding), PLLA memiliki masalah karena sifatnya yang kaku, mudah patah, dan laju kristalisasi yang rendah (Tsuji, 2005). Walaupun kekuatan tensil/luluh (tensile strength) dan modulus elastiknya sebanding dengan plastik berbasis minyak bumi, nilai toughness yang rendah akan membatasi penggunaannya dalam aplikasi komersial yang membutuhkan ketahanan terhadap deformasi pada level aplikasi beban yang tinggi (high stress level) (Gui dkk., 2012).

Untuk mengatasi masalah tersebut, beberapa penelitian telah dilakukan untuk memodifikasi sifat fisik PLLA melalui beberapa metode umum yaitu blending, kopolimerisasi, dan proses pembuatan komposit (Pan dkk., 2009). Blending dua jenis polimer atau lebih merupakan proses modifikasi PLLA yang umum dan ekonomis karena hanya memanfaatkan interaksi fisik antara kedua jenis polimer yang digabungkan (Auras dkk., 2010). Modifikasi PLLA dengan polimer lain menggunakan metode solution blending telah terbukti dapat meningkatkan elastisitas dan biodegradabilitas PLLA. Pada umumnya, plasticizer seperti poli(etilen glikol) (PEG) dapat meningkatkan nilai elongation at break PLLA dari $1 \%$ hingga 10\% (Sheth dkk., 1997; Hassouna dkk., 2011). Younes and Cohn (1998) melaporkan bahwa poli(Lasam laktat) (PLLA) dan PEG dapat membentuk larutan campuran yang miscible pada saat komposisi PEG sebesar 0-20\% berat.

\section{METODE PENELITIAN}

\section{Metoda Eksperimen dan Metoda Karakterisasi Polimer Blend}

Modifikasi sifat fisik poli(L-asam laktat) (PLLA) dilakukan dengan solution blending (pencampuran larutan) terhadap kelompok poli(asam laktat) (PLA) untuk meningkatkan sifat polimer dan sifat kemampuan terbiodegradasi. Dalam penelitian ini, PLLA komersial akan dimodifikasi sifatnya dengan PDLLA, yang merupakan hasil polikondensasi langsung dari monomer asam laktat campuran (Lee dkk., 2013). Metode modifikasi menggunakan metode solution blending. Hasil polimer blend PLLA/PDLLA kemudian dianalisis gugus fungsi, sifat termal, mekanik, dan kemampuan terbiodegradasinya dan dibandingkan dengan polimer blend PLA/PEG pada komposisi yang sama.

\section{Bahan dan Alat}

Bahan terdiri dari poli(D,L-asam laktat) (PDLLA) hasil sintesis melalui polikondensasi langsung pada temperatur $180^{\circ} \mathrm{C}$ dan tekanan 10 torr selama 30 jam dan memiliki berat molekul (Mv) sebesar 79.000 gram/mol. Biji plastik komersial PLLA $(\mathrm{Mn}=148.000 \mathrm{gram} / \mathrm{mol})$ sebagai matriks polimer disuplai oleh LG Chemical Company, South Korea dan merupakan hasil polimerisasi bahan baku LA yang berasal dari biomassa yang bersifat biodegradable. PEG 400 komersial sebagai plasticizer dibeli dari Merck, diklorometana teknis dan etanol 96\% dari PT. Bratachem, enzim proteinase K (lipophylic) yang diproduksi oleh Sigma-Aldrich, sedangkan buffer karbonat $\left(\mathrm{NaHCO}_{3}-\mathrm{Na}_{2} \mathrm{CO}_{3}\right) \mathrm{pH} 8,5$, aqua bidistilasi, dan natrium azida, dibeli dari Merck. 
Produksi Polimer Blend PLA (Insyani, 2014)

Polimer (PLLA, PDLLA, dan PEG), dengan masing-masing berat 1,25 gram, dilarutkan terlebih dahulu dengan pelarut campuran diklorometana-etanol volume $25 \mathrm{ml}$. Kedua larutan polimer dicampurkan (PLLA/PDLLA dan PLLA/PEG) melalui metode solution-blending selama dua sampai tiga jam pada kondisi temperatur $25^{\circ} \mathrm{C}$ di dalam water bath yang dilengkapi dengan pengendali temperatur dan tekanan atmosferik. Komposisi PDLLA dan PEG terhadap PLLA divariasikan dengan rasio 0-20\%-berat. Kemudian larutan polimer hasil blending dicetak dengan metode solvent-casting (Auras dkk., 2010) di atas cetakan dan dikeringkan selama 24 jam pada temperatur $25^{\circ} \mathrm{C}$. Semua film polimer blend PLLA/PDLLA dan PLLA/PEG kemudian dianalisis gugus fungsi, sifat termal, sifat mekanis dan kemampuan biodegradasinya, yang dijelaskan dalam paragraf berikut.

Metoda Karakterisasi Polimer Blend PLA Analisis gugus fungsi dengan spektroskopi Fourier Transform Infrared (FTIR)

Film PLLA dan PLLA/PDLLA dan PLLA/PEG dimasukkan ke dalam tempat sampel pada peralatan FTIR (IRPrestige-21 Shimadzu). Spektra infra merahnya direkam pada bilangan gelombang 500 $\mathrm{cm}^{-1}-4000 \mathrm{~cm}^{-1}$.

\section{Analisis sifat mekanis dengan universal testing machine (UTM).}

Film polimer-blend dibentuk dengan ukuran yang seragam, yaitu panjang $100 \mathrm{~mm}$ dan lebar 28 $\mathrm{mm}$. Uji tarik dilakukan dengan alat UTM (TESTONE, TO-101) pada kecepatan tarik 12,5 $\mathrm{mm} /$ detik. Pengukuran dilakukan dengan menguji 4 spesimen untuk setiap sampelnya.
Analisis sifat termal dengan differential scanning calorimetry (DSC)

Sampel diuji dengan peralatan DSC (TA Instruments, DSC 2010) pada rentang suhu $25-250^{\circ} \mathrm{C}$ dengan kecepatan pemanasan $10^{\circ} \mathrm{C} /$ menit. Data yang diperoleh berupa termogram pola laju alir panas (heat flow) ketika dipanaskan dari suhu $25-250^{\circ} \mathrm{C}$ pada pemanasan kedua (second heating). Sebagai catatan, pemakaian pemanasan pertama (scan pertama) pada umumnya tidak dapat langsung digunakan untuk mendeteksi temperatur kristalisasi $\left(\mathrm{T}_{\mathrm{c}}\right)$.

\section{Analisis degradasi enzimatik dengan enzim Proteinase $\mathrm{K}$}

Semua sampel film polimer-blend dipotong dengan ukuran $20 \mathrm{~mm} \times 10 \mathrm{~mm}$ dimasukkan ke dalam vial yang mengandung $5 \mathrm{ml}$ buffer karbonat $\left(\mathrm{NaHCO}_{3}-\mathrm{Na}_{2} \mathrm{CO}_{3}\right)$ dengan pH 8,$5 ; 0,25 \quad \mathrm{mg}$ Proteinase K; dan $1 \mathrm{mg}$ natrium azida.

Uji degradasi dilakukan pada suhu $37^{\circ} \mathrm{C}$ dalam shaking incubator dengan kecepatan $140 \mathrm{rpm}$. Uji degradasi dilakukan pada setiap sampel selama 48 jam. Sampel diambil secara periodik, dicuci dengan air destilasi, dan dikeringkan dalam oven $30^{\circ} \mathrm{C}$ pada temperatur ruang selama 24 jam. Sampel kering setelah degradasi kemudian ditimbang untuk menghitung persen berat hilang selama uji degradasi.

\section{HASIL DAN PEMBAHASAN}

Pengaruh Penambahan PDLLA dan PEG pada Struktur PLLA

Gambar 1 dan Gambar 2 berturut-turut menunjukkan hasil spektra FT-IR dari polimer dan polimer blend dan spectra FT-IR pada bilangan gelombang $1000-800 \mathrm{~cm}^{-1}$. Hasil analisa gambargambar, terhadap spectra tersebut diberikan dalam bentuk Tabel 1.

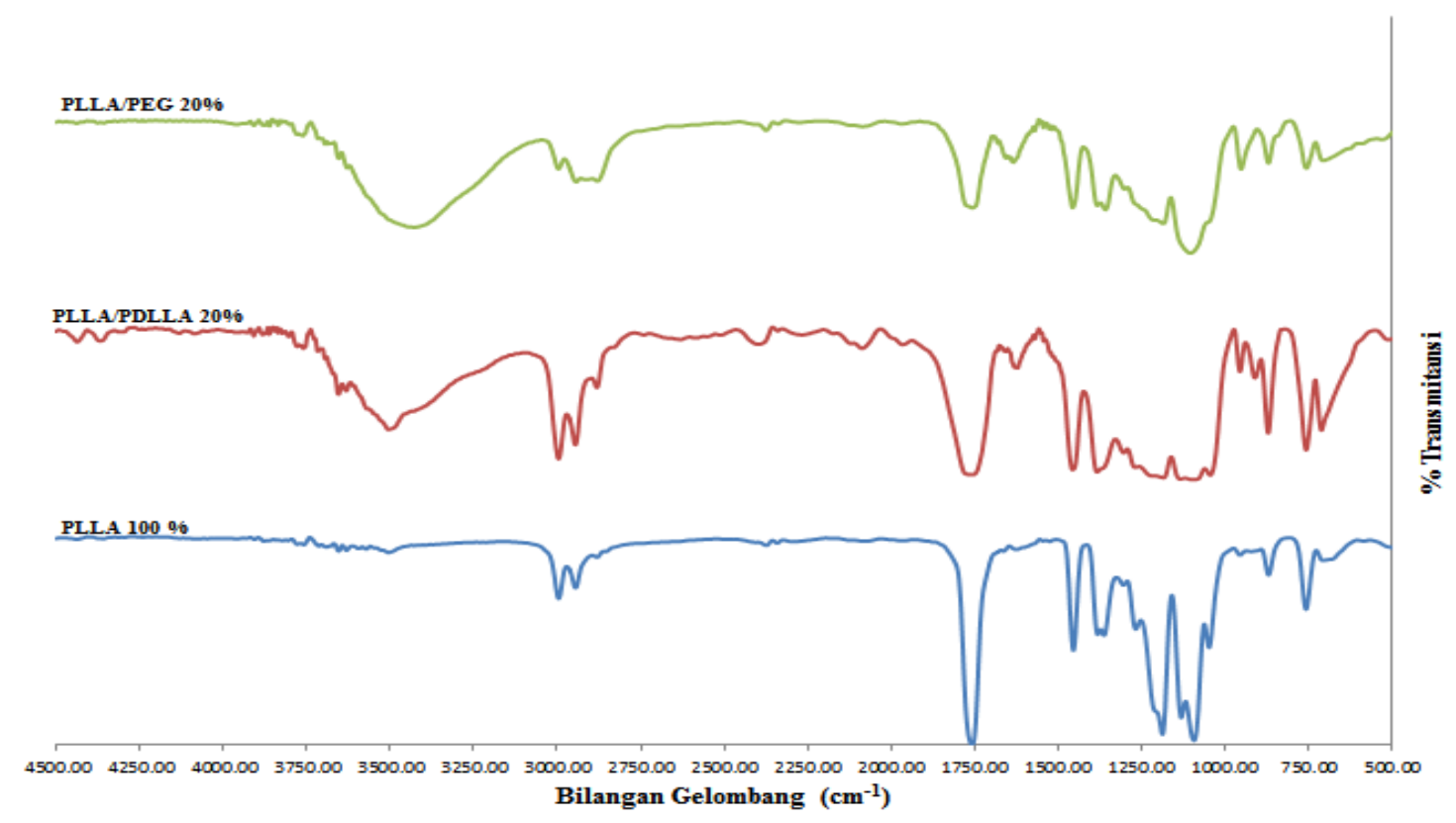

Gambar 1. Spektra FT-IR sampel PLLA, PLLA/PDLLA 20\% dan PLLA/PEG 20\% 


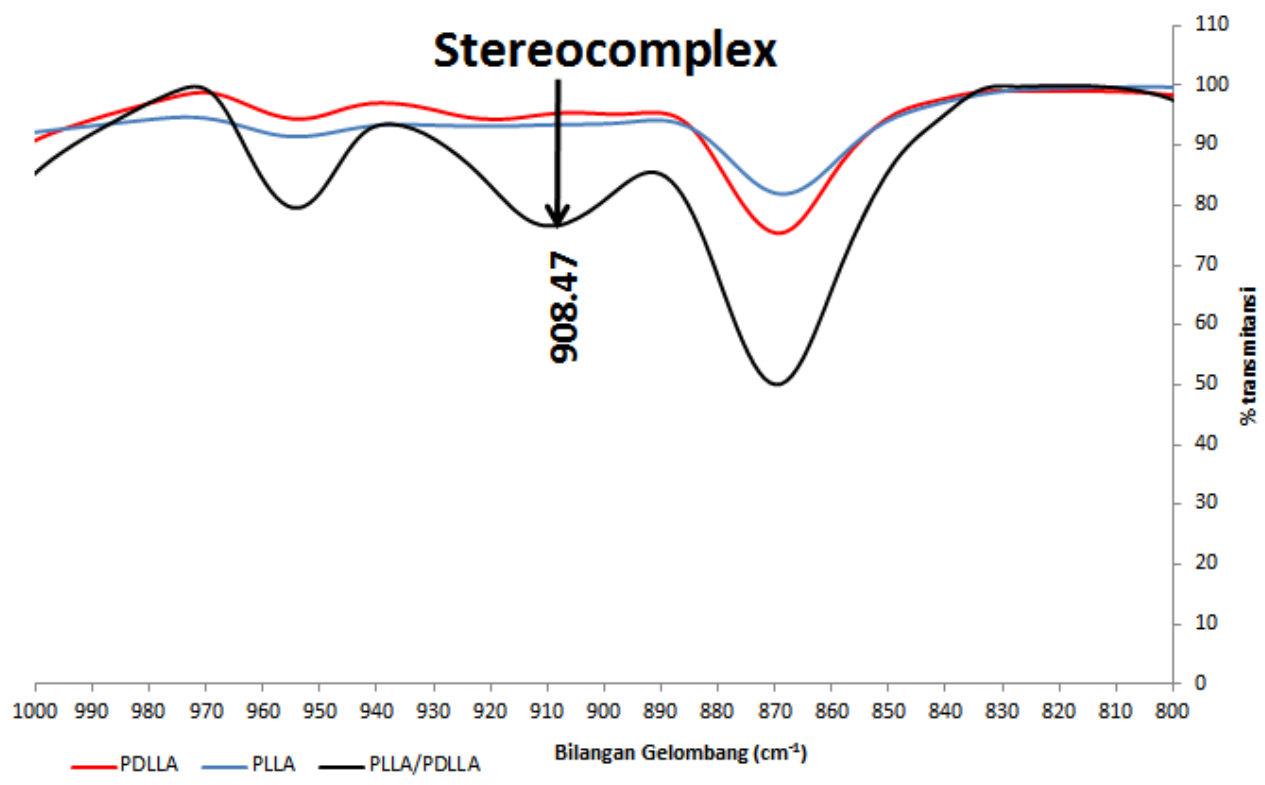

Gambar 2. Spektra FTIR PLLA, PDLLA, dan PLLA/PDLLA $20 \%$ pada bilangan gelombang $1000-800 \mathrm{~cm}^{-1}$

Tabel 1. Data puncak serapan IR khas untuk polimer blend PLA

\begin{tabular}{llll}
\hline Gugus Fungsi & PLLA & PLLA/PDLLA 20\% & PLLA/PEG 20\% \\
\hline Hidroksil (-OH) & 3504 & 3504 & 3429 \\
Karbonil $(-\mathrm{C}=\mathrm{O})$ & 1757 & 1755 & 1757 \\
Metil Simetrik $\left(-\mathrm{CH}_{3}\right)$ & 1381 & 1382 & 1381 \\
\hline
\end{tabular}

Sedangkan pada sampel polimer-blend PLLA/PEG, menunjukkan pola interaksi berbeda. Interaksi antar rantai PLLA dan PEG terjadi pada daerah vibrasi gugus hidroksil yang ditandai dengan pergeseran besar puncak serapan hidroksil dari 3504 $\mathrm{cm}^{-1}$ menjadi $3429 \mathrm{~cm}^{-1}$. Sedangkan serapan vibrasi karbonilnya tidak teramati adanya perubahan. Hal ini membuktikan bahwa terdapat interaksi kuat gugus -OH pada ujung rantai PLLA dengan - OH pada PEG membentuk ikatan hidrogen dan kemungkinan tidak terjadi interaksi pada gugus fungsi karbonil.

Pergeseran puncak serapan hidroksil juga telah disampaikan oleh Kister dkk. (1998). Mereka melaporkan bahwa terdapat pergeseran puncak serapan spektra IR dan Raman pada PLA stereokompleks. Lebih lanjut, Zhang dkk. (2005) melaporkan bahwa pada spektra FTIR PLA teramati pergeseran puncak serapan sangat kecil sebesar 1 $\mathrm{cm}^{-1}$ pada vibrasi gugus fungsi $\mathrm{CH}_{3}$ asimetrik dari $2995 \mathrm{~cm}^{-1}$ menjadi $2994 \mathrm{~cm}^{-1}$ dan vibrasi gugus fungsi karbonil $(\mathrm{C}=\mathrm{O})$ dari $1754 \mathrm{~cm}^{-1}$ menjadi 1749 $\mathrm{cm}^{-1}$ pada saat kristalisasi stereokompleks PLA. Pergeseran ini dapat dijelaskan secara detail sebagai berikut. Adanya interaksi antara $\mathrm{CH}_{3} \ldots \mathrm{O}=\mathrm{C}$ akan membentuk ikatan hidrogen (Tsuji, 2005; Zhang dkk., 2005) dan juga adanya interaksi van der Waals antara hidrogen dari gugus $\mathrm{CH}_{3}$ dan oksigen dari gugus $\mathrm{O}=\mathrm{C}$. Lebih jauh, ikatan hidrogen antara $\mathrm{CH}_{3} \ldots \mathrm{O}=\mathrm{C}$ merupakan driving force (gaya pendorong) terjadinya nukleasi dari kristalit PLA stereokompleks (Tsuji, 2005; Zhang dkk., 2005; Brizzolara dkk., 1996).

Pada penelitian ini, diperoleh hasil struktur stereokompleks yang terbentuk pada polimer blend yang mengandung komponen PDLLA (Gambar 2). Untuk sampel polimer blend PLLA/PDLLA terdapat pergeseran kecil pada puncak serapan gugus fungsi karbonil dari $1757 \mathrm{~cm}^{-1}$ menjadi $1755 \mathrm{~cm}^{-1}$ dan pergeseran sangat kecil pada puncak serapan gugus fungsi deformasi $\mathrm{CH}_{3}$ simetrik dari bilangan gelombang $1381 \mathrm{~cm}^{-1}$ (PLLA) menjadi $1382 \mathrm{~cm}^{-1}$ (PLLA/PDLLA 20\%-berat). Zhang dkk. (2005) melaporkan bahwa analisis stereokompleks PLLA/PDLA dapat diobservasi pada rentang bilangan gelombang $1500-1300 \mathrm{~cm}^{-1}$, lebih spesifk puncak pita serapan pada mode $\mathrm{CH}_{3}$ asimetrik (1455 $\left.\mathrm{cm}^{-1}\right)$ dan deformasi $\mathrm{CH}_{3}$ simetrik $\left(1383 \mathrm{~cm}^{-1}\right)$.

Selain itu, analisis spektra FTIR pada bilangan gelombang $1000-800 \mathrm{~cm}^{-1}$ menunjukkan temuan yang sangat mirip dengan literatur yang disampaikan oleh Zhang dkk. (2005) yang menunjukkan adanya karakteristik pita serapan PLLA/PDLLA stereokompleks dalam bentuk kristal $\beta$ yaitu pada bilangan gelombang 908,47. Hal ini membuktikan bahwa terdapat interaksi antara gugus fungsi metil simterik dengan gugus fungsi karbonil berupa ikatan hidrogen $\mathrm{CH}_{3} \ldots \mathrm{O}=\mathrm{C}$ yang memungkinkan terbentuknya struktur stereokompleks (Tsuji, 2005). 


\section{Pengaruh Penambahan PDLLA dan PEG pada Sifat Termal PLLA}

Gambar 3 menunjukkan termogram dari Differential Scnning Chromatography (DSC) dan hasil analisis terhadap data DSC ini diberikan secara singkat di Tabel 2. Dari Tabel 2 diperoleh Homopolimer PLLA $\mathrm{T}_{\mathrm{m}}$ sebesar $176,65^{\circ} \mathrm{C}$ dan $\Delta \mathrm{H}_{\mathrm{m}}$ sebesar 57,92 J/g. Kristalinitas film polimer PLLA diperoleh sebesar $62,28 \%$. Untuk semua polimerblend PLLA, terjadi penurunan titik leleh $\left(\mathrm{T}_{\mathrm{m}}\right.$ dan $\left.\Delta \mathrm{H}_{\mathrm{m}}\right)$, untuk semua polimer-blend dibandingkan PLLA murni. Menurut Park dkk. (1999) menjelaskan bahwa fenomena ini umum terjadi pada sistem yang blend miscible dan compatible (Pan dkk., 2009).

Pada polimer-blend PLLA/PDLLA, muncul dua puncak temperatur leleh dimana $\mathrm{T}_{\mathrm{m} 2}\left(206^{\circ} \mathrm{C}\right)$ nilainya lebih tinggi dibandingkan $\mathrm{T}_{\mathrm{m} 1}\left(172,79^{\circ} \mathrm{C}\right)$ dan $T_{m}$ PLLA murni $\left(176,65^{\circ} \mathrm{C}\right)$. Nilai $\mathrm{Tm}_{2}$ meningkat dengan peningkatan komposisi PDLLA dari 10-20\%-berat. Puncak $\mathrm{T}_{\mathrm{m}}$ pada sekitar $170^{\circ} \mathrm{C}$ merupakan temperatur pelelehan homokristalit PLLA sedangkan puncak $\mathrm{T}_{\mathrm{m}}$ yang berada pada $206^{\circ} \mathrm{C}$ merupakan puncak khas dari stereokompleks (Tsuji, 2005). Peningkatan komposisi PDLLA menyebabkan $\mathrm{T}_{\mathrm{m}}$ stereokompleks polimer blend semakin meningkat, hal ini menunjukkan bahwa pembentukan struktur stereokompleks semakin mudah hingga mencapai nilai maksimum pada rasio equimolar PLLA dan PDLA.

Polimer blend PLLA/PDLLA, kristalinitas sampel terbagi menjadi dua jenis yaitu, kristalinitas homokristalit PLLA $\left(\mathrm{X}_{\mathrm{HC}}\right)$ dan kristalinitas stereokompleks kristalit $\left(\mathrm{X}_{\mathrm{SC}}\right)$. Hasil perhitungan menunjukkan penurunan persen kristalinitas homokristalit PLLA $\left(\mathrm{X}_{\mathrm{HC}}\right)$ hingga $27,18 \%$ pada komposisi PDLLA sebesar 20\%-berat, sedangkan kristalinitas stereokompleksnya meningkat dengan nilai maksimum $17,63 \%$ pada komposisi PDLLA sebesar 20\%-berat.

Pada polimer blend PLLA/PEG, perilaku puncak pelelehan $\left(\mathrm{T}_{\mathrm{m}}\right.$ dan $\left.\Delta \mathrm{H}_{\mathrm{m}}\right)$ tunggal. Puncak tunggal ini disebabkan karena adanya satu daerah fasa kristalin yang terbentuk pada saat blending PLLA/PEG 10\%. Selain itu puncak $\mathrm{T}_{\mathrm{g}}$ tunggal polimer blend PLLA/PEG menunjukkan bahwa polimer blend bersifat miscible. Terjadi penurunan puncak temperatur leleh pada peningkatan komposisi PEG dari 10-20\%-berat dan peningkatan kristalinitas $\left(\mathrm{X}_{\mathrm{HC}}\right)$. Tidak muncul puncak pelelehan baru $\left(\mathrm{Tm}_{2}\right.$ dan $\Delta \mathrm{Hm}_{2}$ ) pada temperatur sekitar $200^{\circ} \mathrm{C}$ karena tidak terjadi pembentukan struktur stereokompleks, didukung dengan spektrum FTIR yang tidak menunjukkan pergeseran puncak serapan akibat interaksi stereokompleks.

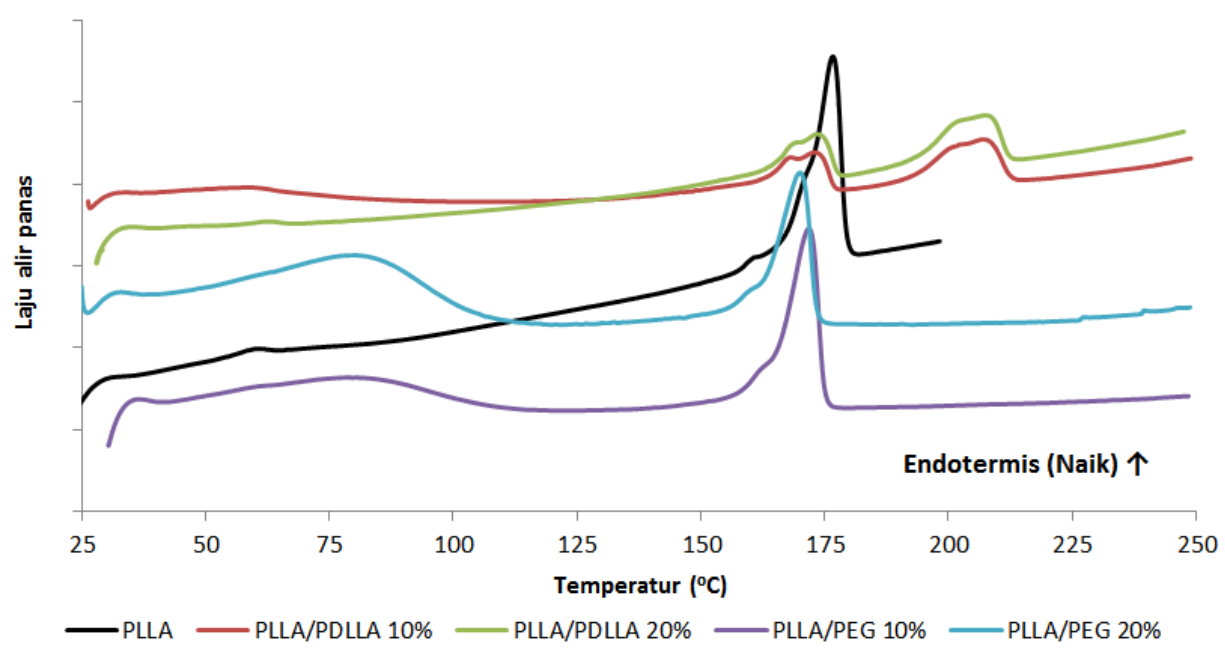

Gambar 3. Termogram DSC sampel PLLA dan polimer blend-nya

Tabel 2. Temperatur leleh dan kristalinitas polimer blend PLA

\begin{tabular}{ccccccc}
\hline \multirow{2}{*}{ Sampel } & \multicolumn{2}{c}{ Temperatur $\left({ }^{\circ} \mathrm{C}\right)$} & \multicolumn{2}{c}{ Entalpi $(\mathrm{J} / \mathrm{g})$} & \multicolumn{2}{c}{ Kristalinitas $(\%)$} \\
\cline { 2 - 7 } & $\mathrm{T}_{\mathrm{m} 1}$ & $\mathrm{~T}_{\mathrm{m} 2}$ & $\Delta \mathrm{H}_{\mathrm{m} 1}$ & $\Delta \mathrm{H}_{\mathrm{m} 2}$ & $\mathrm{X}_{\mathrm{HC}}$ & $\mathrm{X}_{\mathrm{SC}}$ \\
\hline PDLLA & - & - & - & - & - & - \\
PLLA & 176,65 & - & 57,92 & - & 62,28 & - \\
PLLA 90\%/PDLLA 10\% & 172,79 & 206,39 & 25,53 & 23,70 & 30,50 & 16,69 \\
PLLA 80\%/PDLLA 20\% & 173,24 & 206,96 & 20,22 & 25,03 & 27,18 & 17,63 \\
PLLA 90\%/PEG 10\% & 171,84 & - & 55,31 & - & 66,08 & - \\
PLLA 80\%/PEG 20\% & 170,02 & - & 51,72 & - & 69,52 & - \\
\hline
\end{tabular}

${ }^{*)}$ tidak diperoleh data karena polimer amorf 
Peningkatan kristalinitas $\left(\mathrm{X}_{\mathrm{HC}}\right)$ dijelaskan dengan spektrum FTIR mendeteksi adanya interaksi antara PLLA dan PEG pada bagian hidroksil pada ujung terminal rantai PLLA membentuk ikatan hidrogen yang dapat menginduksi proses kristalisasi PLLA sehingga dapat meningkatkan derajat kristalinitas PLA (Park dkk., 1999; Pan dkk., 2009). Kristalinitas maksimum dicapai pada komposisi PEG $20 \%$-berat sebesar $69,52 \%$.

\section{Pengaruh Penambahan PDLLA dan PEG pada Sifat Mekanis PLLA}

Tabel 3 menunjukkan hasil uji mekanis homopolimer PLLA dan polimer blend PLLA/PDLLA dan PLLA/PEG. PLLA memiliki sifat getas/ brittle yang direpresentasikan dengan modulus elastisitas (E) yang tinggi dimana ketahanan terhadap beban yang tinggi namun elongasinya rendah (Martin dkk., 2001; Pan dkk., 2009; Gui dkk., 2012). Pada penelitian ini, hasil uji mekanis dari film PLLA menunjukkan sifat yang serupa yaitu stress at break $\left(\sigma_{\mathrm{B}}\right)(642,95 \mathrm{kPa})$ dan modulus elastisitas $(\mathrm{E})(314$, $60 \mathrm{kPa})$ yang tinggi sedangkan nilai elongation at break nya $\left(\varepsilon_{\mathrm{B}}\right)$ sangat rendah $(1 \%)$. Modifikasi PLLA dengan polimer biodegradable lain ternyata dapat menurunan nilai modulus elastisitas $(\mathrm{E})$ yang disertai dengan peningkatan nilai elongation at break $\left(\varepsilon_{\mathrm{B}}\right)$.

Nilai modulus elastisitas (E) pada Tabel 3 diperoleh dari perbandingan antara yield stress $\left(\sigma_{\mathrm{y}}\right)$ dengan yield strain $\left(\varepsilon_{\mathrm{y}}\right)$ dimana masing-masing nilai tersebut berada pada daerah linier kurva stress-strain. Sedangkan nilai stress $\left(\sigma_{\mathrm{B}}\right)$ dan elongation at break $\left(\varepsilon_{\mathrm{B}}\right)$, diperoleh dari perhitungan pada term peak load dan peak elongation. Dalam hal ini, istilah peak adalah keadaan ketika sampel tidak lagi mampu menahan beban sehingga sampel rusak atau patah. Peak load dikonversi menjadi peak stress atau stress at break $\left(\sigma_{\mathrm{B}}\right)$.

Tabel 3. Hasil uji mekanis polimer blend PLA

\begin{tabular}{llll}
\hline Sampel & $\sigma_{\mathrm{B}}(\mathrm{kPa})$ & $\varepsilon_{\mathrm{B}}(\%)$ & $\mathrm{E}(\mathrm{kPa})$ \\
\hline PLLA & 642,95 & 1,00 & 314,60 \\
PLLA 90\%/PDLLA 10\% & 746,36 & 2,75 & 349,77 \\
PLLA 80\%/PDLLA 20\% & 537,61 & 6,25 & 237,77 \\
PLLA 90\%/PEG 10\% & 589,22 & 29,50 & 280,77 \\
PLLA 80\%/PEG 20\% & 330,10 & 89,00 & 228,35 \\
\hline
\end{tabular}

Pada sampel polimer-blend PLLA/PDLLA, peningkatan komposisi PDLLA ke dalam matriks PLLA dapat mengubah sifat mekanik PLLA. Hasil uji mekanik menunjukkan bahwa penambahan 10\%berat PDLLA memiliki nilai yang lebih besar dari semua bagian kekuatan mekanis dibandingkan dengan PLLA murni, yaitu $\sigma_{\mathrm{B}}=746,36 \mathrm{kPa}, \varepsilon_{\mathrm{B}}=$ $2,75 \%$, dan $\mathrm{E}=349,77 \mathrm{kPa}$. Sehinga dapat disimpulkan bahwa secara keseluruhan term kekuatan mekanik PLLA/PDLLA 10\%-berat sedikit lebih kuat dibandingkan dengan PLLA murni. Hal ini disebabkan adanya komponen PDLLA memberi kontribusi dalam pembentukan stereokompleks (Tsuji, 2005; Liu dkk., 2014).
Pola sifat mekanik polimer blend PLLA/PEG menunjukkan penurunan $\sigma_{\mathrm{B}}$ dan $\mathrm{E}$, hal ini disebabkan PEG memiliki tensile strength yang lebih rendah dibandingkan PLLA murni (Pan dkk., 2009). Peningkatan komposisi PEG menghasilkan peningkatan nilai $\varepsilon_{\mathrm{B}}$, hal ini lebih disebabkan bahwa PEG selain berperan sebagai agen nukleasi yang dapat meningkatkan kristalinitas PLLA namun pada saat bersamaan PEG berperan sebagai plasticizer (memberikan sifat plastik).

\section{Pengaruh Penambahan PDLLA dan PEG pada Biodegradabilitas PLLA}

Penambahan PDLLA atau PEG melalui solution-blending dapat meningkatkan kemampuan terbiodegradasi PLLA. Gambar 4 menunjukkan persen hilang berat semua sampel polimer-blend PLLA/PDLLA dan PLLA/PEG. Dari Gambar 4(a), untuk blend PLLA/PDLLA, penurunan persen hilang berat tertinggi dicapai pada komposisi PDLLA sebesar 20\%-berat. Dari grafik pada Gambar 4(b) tersebut, sampel PLLA memiliki persen hilang berat terendah pada selang waktu degradasi sampai 48 jam. Sedangkan, sampel polimer-blend memiliki persen hilang berat sampel lebih besar dibandingkan PLLA murni. Hal ini disebabkan karena PLLA merupakan polimer dengan kristalinitas lebih tinggi dibandingkan PLLA/PDLLA (Tsuji dkk., 2001).

Pada sampel PLLA/PDLLA, peningkatan komposisi PDLLA menghasilkan persen hilang berat sampel lebih besar dibandingkan PLLA murni karena memiliki daerah fasa amorf lebih besar yang ditunjukkan dengan penurunan kristalinitas homokristalit PLLA ( $\left.\mathrm{X}_{\mathrm{HC}}\right)$. Sedangkan terjadi penurunan persen hilang berat pada komposisi PDLLA sebesar 20\%-berat yang disebabkan adanya peningkatan kristalinitas stereokompleks ( $\left.\mathrm{X}_{\mathrm{SC}}\right)$. Selain itu, penambahan PDLLA dapat meningkatkan fraksi komposisi unit $\mathrm{D}\left(\mathrm{X}_{\mathrm{D}}\right)$ yang tidak dapat dihidrolisis oleh enzim proteinase $\mathrm{K}$ akibat perbedaan struktur substrat dengan bagian situs katalitik (binding site) enzim. Penurunan persen hilang maksimum mencapai $21 \%$ untuk blend PLLA-PEG.

Pada sampel PLLA/PEG, peningkatan persen komposisi PEG dalam matriks PLLA menunjukkan persen hilang berat terbesar dibandingkan polimer lainnya. Sedangkan data DSC menunjukkan bahwa peningkatan konsentrasi PEG menghasilkan peningkatan kristalinitas homokristalit $\left(\mathrm{X}_{\mathrm{HC}}\right)$. Hal ini kemungkinan disebabkan oleh pelarutan sebagian fraksi PEG media degradasi dapat meningkatkan porositas blend sehingga akan menghasilkan area permukaan film yang lebih besar untuk diakses oleh enzim proteinase K (Sheth dkk., 1997). Lebih jauh, terdapat kemungkinan peningkatan hidrofilisitas pada permukaan film polimer, yang dapat mempercepat degradasi dan juga meningkatkan mobilitas rantai molekul PLA sehingga memberikan kemudahan akses degradasi enzimatik. 

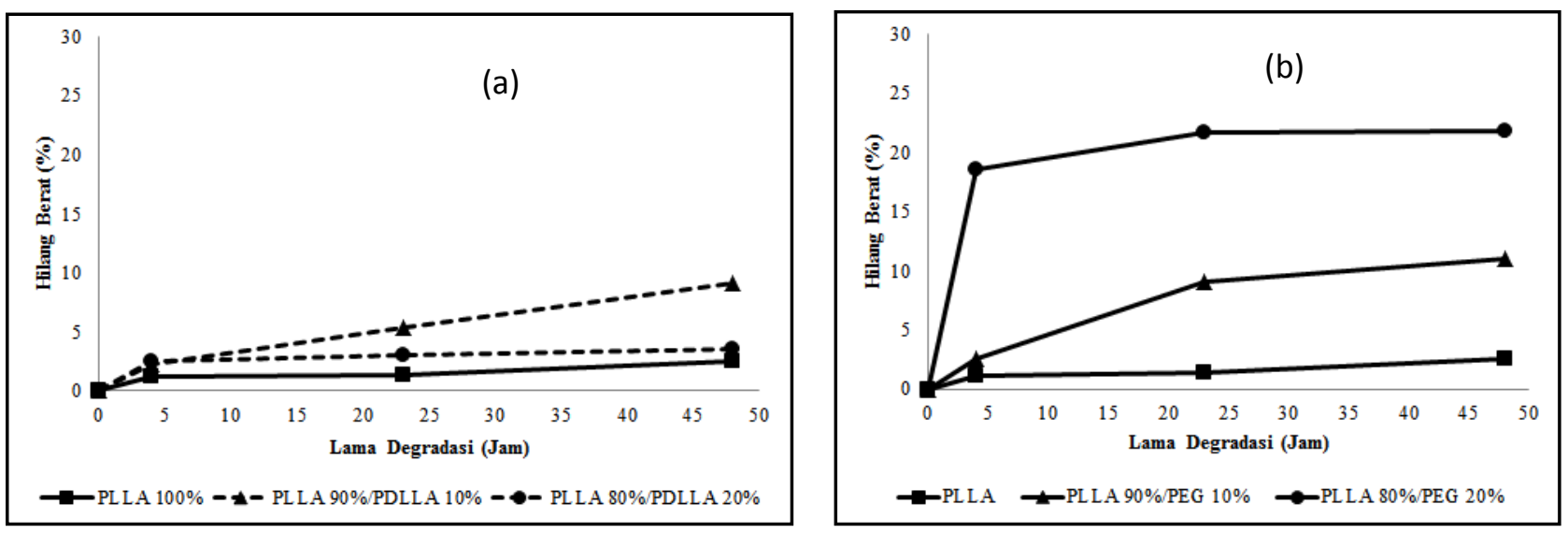

Gambar 4. Grafik hilang berat (\%) (a) sampel PLLA/PDLLA dan (b) sampel PLLA/PEG

\section{KESIMPULAN}

Sifat polimer, khususnya sifat mekanis dan kemampuan terbiodegradasi poli(L-asam laktat) (PLLA) berhasil dimodifikasi dengan biodegradable polymer lain yaitu PDLLA dan PEG dengan metode solution-blending. Penambahan PDLLA dalam matriks PLLA menyebabkan terbentuknya struktur stereokompleks yang dapat meningkatkan properti mekanis PLLA sedangkan penambahan PEG berperan sebagai plasticizer dan agen nukleasi pada homokristalit PLLA. Hasil uji mekanik menunjukkan bahwa penambahan $10 \%$-berat PDLLA memberikan nilai yang lebih besar dari semua bagian kekuatan mekanis dibandingkan dengan PLLA murni. Lebih jauh, Penambahan PDLLA atau PEG melalui solutionblending dapat meningkatkan kemampuan terbiodegradasi PLLA. Untuk blend PLLA/PDLLA, penurunan persen hilang berat tertinggi dicapai pada komposisi PDLLA sebesar 20\%-berat dan untuk blend PLLA-PEG penurunan persen hilang maksimum mencapai $21 \%$.

\section{UCAPAN TERIMA KASIH}

Terima kasih kepada Kementrian Riset dan Teknologi atas pendanaan melalui program Insentif Riset Sistem Inovasi Nasional (SiNas) dan kepada PT Garuda Twin Jaya, Tangerang, untuk pemakaian UTM serta Prof. Won Sun Ryoo, Department of Chemical Engineering, University of Hongik untuk memberikan hasil DSC dalam tulisan ini. Dr. HWL mengucapkan terima kasih atas pendanaan dari National Research Foundation (NRF) Korea Selatan sebagai visiting scholar di program studi Teknik Kimia-FTI ITB.

\section{DAFTAR SIMBOL}

$$
\begin{array}{ll}
\Delta \mathrm{H}_{\mathrm{m}}= & \text { entalpi leleh }(\mathrm{J} / \mathrm{g}) \\
\mathrm{T}_{\mathrm{m}} & =\text { temperatur leleh }\left({ }^{\circ} \mathrm{C}\right) \\
\mathrm{E} & =\text { modulus elastisitas }(\mathrm{kPa}) \\
\mathrm{X}_{\mathrm{HC}}= & \text { fraksi kristalinitas homokristalit }(\%) \\
\mathrm{X}_{\mathrm{SC}}= & \text { fraksi kristalinitas stereokompleks kristalit } \\
& (\%) \\
X & =\text { fraksi/ komposisi }(\%) \\
\sigma & =\text { peak stress }(\mathrm{kPa})
\end{array}
$$

$\sigma_{\mathrm{B}} \quad=$ stress at break $(\mathrm{kPa})$

$\sigma_{\mathrm{y}} \quad=$ yield stress $(\mathrm{kPa})$

$\varepsilon_{\mathrm{y}} \quad=$ yield $\operatorname{strain}(\mathrm{kPa})$

\section{DAFTAR PUSTAKA}

Auras, R., Lim, L.K., Selke, S.M., and Tsuji, H., (2010), POLY(LACTIC ACID): Synthesis, Structures, Properties, Processing, and Applications, John Wiley \& Sons, Inc., New Jersey.

Brizzolara, D., Cantow, H.J., Mulhaupt, R., and Domb, A.J., (1996), Novel Materials through Stereocomplexation, Journal of Computer-Aided Material Design, 3, pp. 341-350.

Gui, Y., Xu, Y., Gao, Y., Lu, C., and Cheng, S., (2012), Novel Poly(ethylene glycol)-based Polyestertoughened Polylactide, Materials Letters, 71, pp. 6365 .

Hassouna, F., Raquez, J.M., Addiego, F., Dubois, P., Toniazzo, V., and Ruch, D., (2011) New approach on the development of plasticized polylactide (PLA): Grafting of poly(ethylene glycol) (PEG) via reactive extrusion, European Polymer Journal, 47, pp. 21342144.

Hirata, M. and Kimura, Y., (2010), Structure and Properties of Stereocomplex-Type Poly(lactic acid), in Poly(Lactic Acid): Synthesis, Structures, Properties, Processing, and Applications (eds R. Auras, L.T. Lim, S.E.M. Selke and H. Tsuji), John Wiley \& Sons, Inc., Hoboken, NJ, USA, pp. 59-65.

Insyani, R., (2014), Sintesis dan Karakterisasi Polimer Blend PLA/ PEG Berbahan Baku Asam Laktat, Tesis Magister, Program Studi Teknik Kimia-Fakultas Teknologi Industri, ITB, Bandung.

Kister, G., Cassanas, G., and Vert, M., (1998), Effects of morphology, conformation and configuration on the IR and Raman spectra of various poly(lactic acid)s, Polymer, 39(2), pp. 267-273. 
Lee, H.W., Insyani, R., Prasetyo, D., Prajitno, H., Rasrendra, C.B., and Sitompul, J.P., (2013), Polycondensation of Biodegradable PLA Synthesis over $\mathrm{Al}_{2} \mathrm{O}_{3}$ and $\mathrm{ZnO}$ Catalyst, paper \# BM-12, Proc. Int'l Seminar on Chemical Engineering 2013, 9-11 October 2013, Bandung, Indonesia (best paper).

Liu, Y., Shao, J., Sun, J., Bian, X., Feng, L., Xiang, S., Sun, B., Chen, Z., Li, G., and Chen, X., (2014) Improved Mechanical and Thermal Properties of PLLA by Solvent Blending with PDLA-b-PEG-bPDLA, Polymer Degradation and Stability, 101, pp. 10-17.

Martin, O. and Avrous, L., (2001), Poly (Lactic acid): Plasticization and Properties of Biodegradable Multiphase Systems, Polymer, 42(14), pp. 6209-6219.

Pan, P., Liang, Z., Zhu, B., Dong, T., and Inoue, Y., (2009), Blending Effects on Polymorphic Crystallization of Poly(L-lactide), Macromolecules, 42, pp. 3374-3380.

Park, J.W., Lee, D.J., Yoo, W.J., Yoo, E.S., and Im, S.S., (1999), Biodegradable Polymer Blends of Poly(lactic acid) and Starch, Korean Polymer Journal, 7(2), pp. 93-101.

Rein, J., (2010), Biodegradable Poly(Lactic Acid): Synthesis, Modification, Processing and Applications, Springer Heidelberg Dordrecht, London.
Sheth, M., Kumar, R.A., Dave, V., Gross, R.A., and McCarthy, S.P., (1997), Biodegradable Polymer Blends of Poly (lactic acid) and poly (ethylene glycol), Journal of Applied Polymer Science, 66, pp. 14951505 .

Sitompul, J.P., Simangunsong, R.F., Asrizal, A.A., Alisyahbana, H., Lee, H.W., and Rasrendra, C.B., (2014), Catalytic Conversion of Empty Fruit Bunch of Palm Oil for Producing Lactic Acid, Procedia Chemistry, 9, pp. 82-89.

Tsuji, H. and Miyauchi, S., (2001), Enzymatic hydrolysis of poly(lactide)s: effects of molecular weight, L-lactide content, and enantiomeric and diastereoisomeric polymer blending, Biomacromolecules, 2, pp. 597-604.

Tsuji, H., (2005) Poly(lactide) Stereocomplex: Formation, Structure, Properties, Degradation, and Application, Macromolecular Bioscience, 5, pp. 569597.

Younes, H. and Cohn, D., (1988), Phase Separation in Poly(ethylene glycol)/Poly(lactic acid) Blends, European Polymer Journal, 24(8), 765-773.

Zhang, J., Sato, H., Tsuji, H., Noda, I., and Ozaki, Y., (2005) Infrared Specrtropic study of $\mathrm{CH}_{3} \ldots \mathrm{O}=\mathrm{C}$ interaction during poly(L-lactide)/poly(D-lactide) stereocomplex formation, Macromolecules, 38, pp. $1822-1828$ 